\title{
NUP93 wt Allele
}

National Cancer Institute

\section{Source}

National Cancer Institute. NUP93 wt Allele. NCI Thesaurus. Code C150285.

Human NUP93 wild-type allele is located in the vicinity of $16 q 13$ and is approximately 120 $\mathrm{kb}$ in length. This allele, which encodes nuclear pore complex protein Nup93, plays a role in nuclear import. 